\title{
Groundwater Evaluation and Management in Ain Sukhna, Egypt
}

\author{
Alaa Nabil El-Hazek ${ }^{1}$, Neveen B. Abdelmageed ${ }^{2}$, Hatem M. Mekhemer ${ }^{3}$ and Dalia H. Amin ${ }^{4 *}$ \\ ${ }^{1}$ Civil Engineering Department, Faculty of Engineering at Shoubra, \\ Cairo, Benha University, Egypt \\ ${ }^{2}$ Civil Engineering Department, Faculty of Engineering at Shoubra, \\ Cairo, Benha University, Egypt \\ ${ }^{3}$ Water Resources Research Institute \\ National Water Research Center, Egypt \\ ${ }^{4}$ Water Resources Research Institute \\ National Water Research Center, Egypt \\ *Corresponding author's email: engdalia.work [AT] gmail.com
}

\begin{abstract}
Ain Sukhna has become one of the most important economic areas in Egypt recently. As a result of this economic development, the demand for water has increased, with special emphasis on groundwater. Therefore, in this paper, several scenarios are assessed in order to reach the best scenario for groundwater management giving the opportunity to achieve the development needs of that region.Groundwater Modeling System (GMS) software is used to construct the solid model forsimulating the geometry of the aquifer layers. Then, a conceptual model is developed and calibrated in steady state case. The calibration results are satisfactory showing a good agreement between the calculated and observed heads. Finally, four scenarios are simulated with different pumping possibilities ranging from $-25 \%$ to $+50 \%$ of the current pumping rates. The results show that it will be better if the current pumping rate is reduced by $25 \%$ which can make the drawdown values less than the other possibilities. It is also shown that the best recommended places to drill more wells can be in the east and south directions where the least drawdown values are found.
\end{abstract}

Keywords--- Groundwater Assessment, Groundwater Management, Numerical Modeling, Ain Sukhna, GMS

\section{INTRODUCTION}

Over the last years, one of the challenges facing development and investment plans in the Ain Sukhna region, as an arid area, wasthe lack of water resources [1]. The solution was to find other unconventional water sources such as groundwater. Therefore, Ain Sukhna region was the subject of interest for lots of geological, hydrogeological and geophysical studies carried out by many authors such as [2-14].

For the last decade, the studies have increased significantly due to the economic development of this region.[15] conducted geoelectrical study on the quaternary aquifer in the deltas of wadi Badaa and Ghweiba in Ain Sukhna area.It showed that the quaternary aquifer was the major promising aquifer having slightly fresh to brackish water class. Also, [16] used three geophysical techniques to explore the hydrogeological conditions in the study area. The integration of the results confirmed the existence of the quaternaryaquifer which lied next to unsaturated zone with a thickness range between 1.0 and $3.5 \mathrm{~m}$. Another geophysical investigation in the northwestern part of the Gulf of Suez also confirmed that the aquifer was found with a total depth ranged between few meters to $25 \mathrm{~m}$ [17].

Groundwater modeling was used in many previous studies at many regions all over Egypt, but not Ain Sukhna region.Groundwater model was performed onthe Post Nubian and Nubian aquifers in Farafra Oasis by [18] to obtain optimal pumping rate during different simulation periods. Another groundwater modeling study was conducted forthe quaternary aquifer Eastern Nile Delta by [19] to determine the effect of different pumping rates scenarios. This present considers assessing and managing the groundwater aquifers in Ain Sukhna using the groundwater modeling.

\section{MATERIAL AND METHODS}

Mathematical models of groundwater flow are based on a partial differential equation (1) that used in MODFLOW software [20]: 


$$
\frac{\partial}{\partial X}\left(K_{X X} \frac{\partial h}{\partial X}\right)+\frac{\partial}{\partial Y}\left(K_{Y Y} \frac{\partial h}{\partial Y}\right)+\frac{\partial}{\partial Z}\left(K_{Z Z} \frac{\partial h}{\partial z}\right)+W=S_{s} \frac{\partial h}{\partial t}
$$

Where:

$\mathrm{K}_{\mathrm{xx}}, \mathrm{K}_{\mathrm{yy}}$, and $\mathrm{K}_{\mathrm{zz}}$ are the values of hydraulic conductivity along the $\mathrm{x}, \mathrm{y}$ and $\mathrm{z}$ coordinate axes, which are assumed to be parallel to the major axes of the hydraulic conductivity [L/T],

$\mathrm{h}$ is the hydraulic head [L],

$\mathrm{W}$ is a volumetric flux per unit volume representing sources and/or sinks of water, $(\mathrm{W}<0.0$ for flow out of the groundwater system, and $\mathrm{W}>0.0$ for flow in the system) $\left[\mathrm{T}^{-1}\right]$,

$\mathrm{S}_{\mathrm{S}}$ is the specific storage of the porous material $\left[\mathrm{L}^{-1}\right]$,

and $\mathrm{t}$ is the time, $[\mathrm{T}]$.

These mathematical models of groundwater flow can be solved generally with two approaches; the analytical and the numerical solutions.

According to [21], the data required to formulate and solve such models include geometry, aquifer parameters, and inflows/outflows.

In this paper, following data were collected and processed to set up all the model stages:

a. Borehole logs from drillings, to recognize the different lithological compositions of the aquifers required for the solid model building.

b. Data of wells, which include groundwater level measurements, discharging rates of the wells and design of wells.

c. Aquifer main recharge, which is resulted from the two sources in the study area (rainfall and floods of wadis) and is estimated by two methods: Soil Conservation Service curve number (SCS) method and Water Balance method.

d. Hydraulic Properties of the aquifers, to calculate the hydraulic conductivity, transmissivity and storage coefficient values.

\section{STUDY AREA}

The study area is in the northwestern part of Gulf of Suez with an area of about $400 \mathrm{~km}^{2}$. It is enclosed between latitudes $29^{\circ} 31^{\prime} 03^{\prime \prime}$ and $29^{\circ} 46^{\prime} 04^{\prime \prime} \mathrm{N}$ and longitudes $31^{\circ} 58^{\prime} 58^{\prime \prime}$ and $32^{\circ} 24^{\prime} 51^{\prime \prime}$ E. It is bounded westward by a group of mountains which extend from the far north of the Gulf of Suez Mount Ataka to Mount El-Galala El-Bahariya in the south. As shown in Figure (1), these mountains contain four wadis which are Wadi Hommath, Wadi Hagoul, Wadi Bada and Wadi Ghweiba.

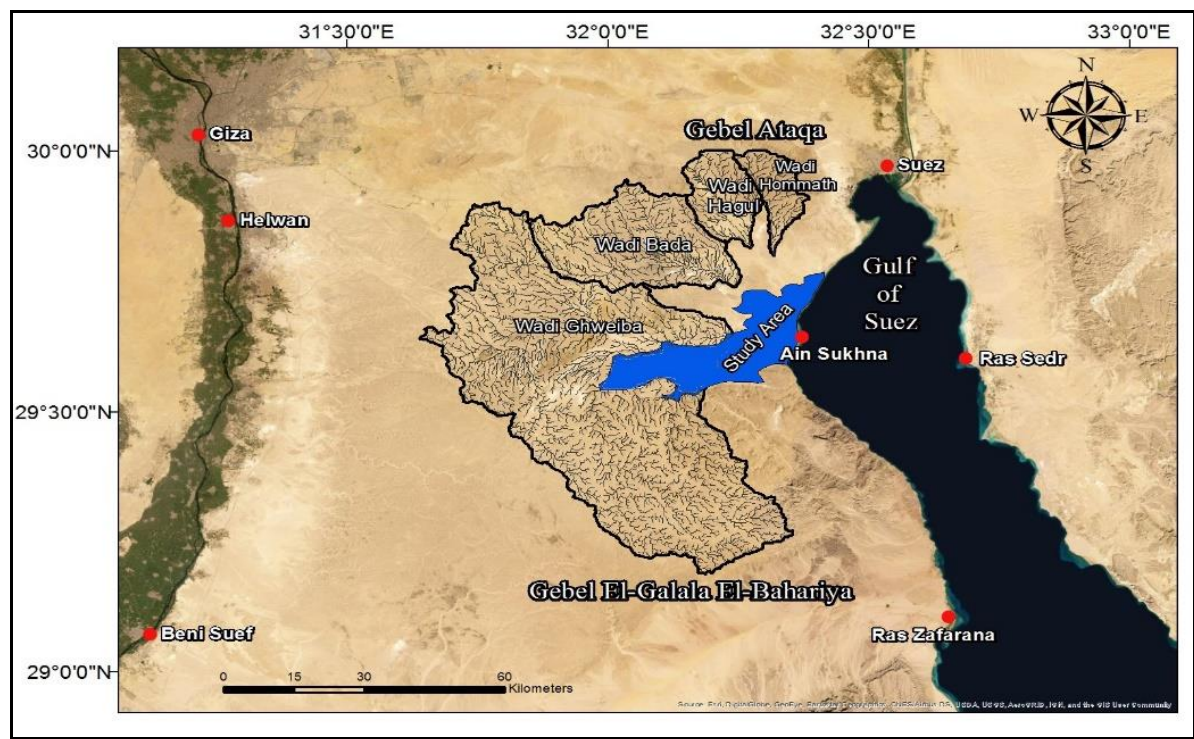

Figure (1): A Map of the Wadis of Study Area

The study area is also characterized by three main geomorphological units, which are flat areas at the main streams of the wadis and its tributaries, terraces at the middle part of the study area, and mountainous areas at northern western 
north and southern parts of the study area. The geologic features of the study area contain different lithological units with different ages ranging from the quaternary to the lower cretaceous time.

The study area consists of three different aquifers. The first aquifer belongs to the quaternary consisting of coarse sand, gravel, silt, some intercalations of clay and fine to medium sand. The second aquifer belongs to both Miocene and Eocene and consists of limestone, some intercalations of clay, sand and gravel. Finally, the third aquifer belongs to Cretaceous that consists of sandstone with some intercalations of shale.

\section{ANALYSES OF DATA}

Groundwater Modeling System (GMS) software was used to develop the model for the study area, asillustrated in Figure (2).

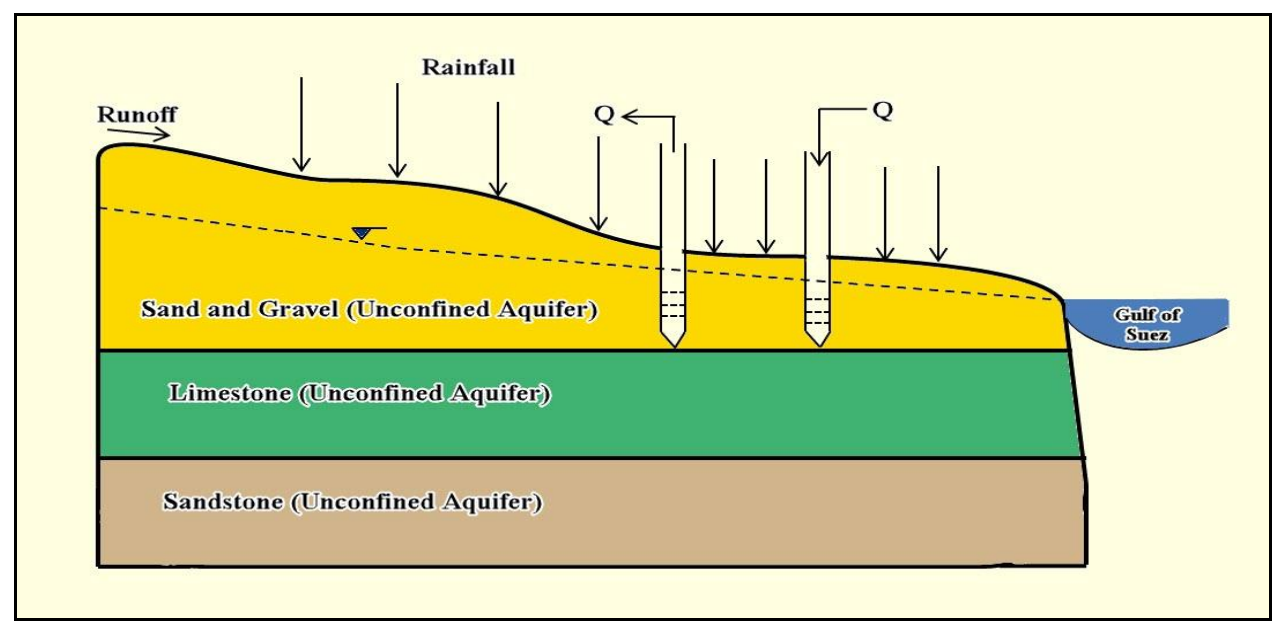

Figure (2): The Model of the Study Area

The model of the study area consisted of three hydrogeological units representing the sand and gravel aquifer, the limestone aquifer and the sandstone aquifer, as shown in Figure (3).

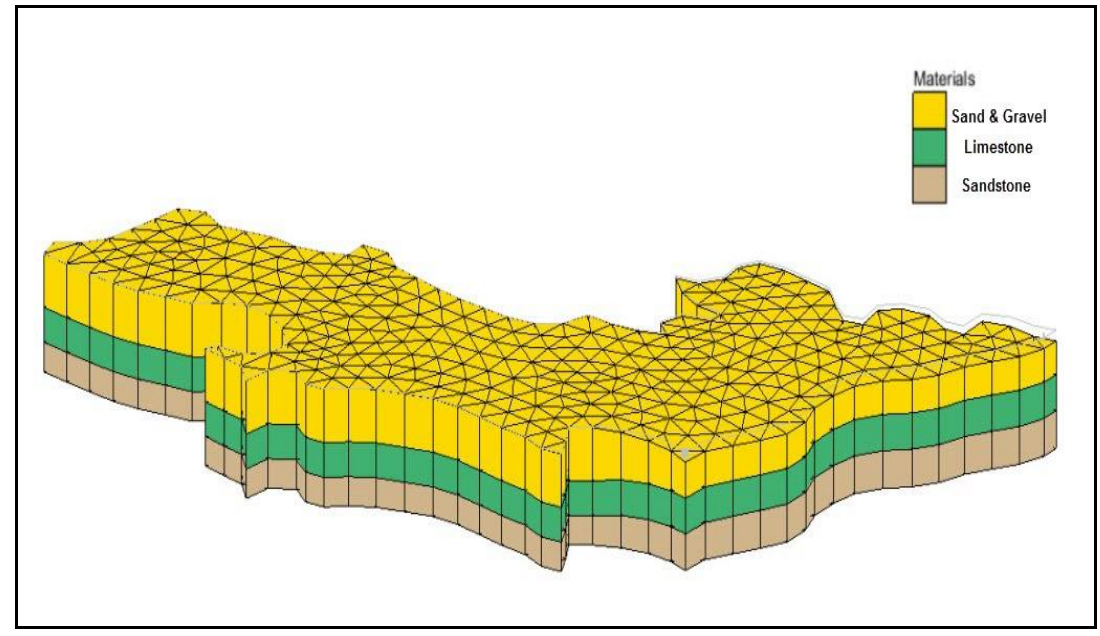

Figure (3): 3D-View of the Three Aquifers of the Study Area

$[22,23]$ discussed different types of physical features and their equivalent mathematical representations.In the study area,as shown in Figure (4), three types of boundaries were assigned in the model; constant head boundary (the eastern side of the aquifer), no flow boundary (the northwest- southwest and western side of the aquifer), and specified flow boundary (the outlet of the wadis in the study area). 


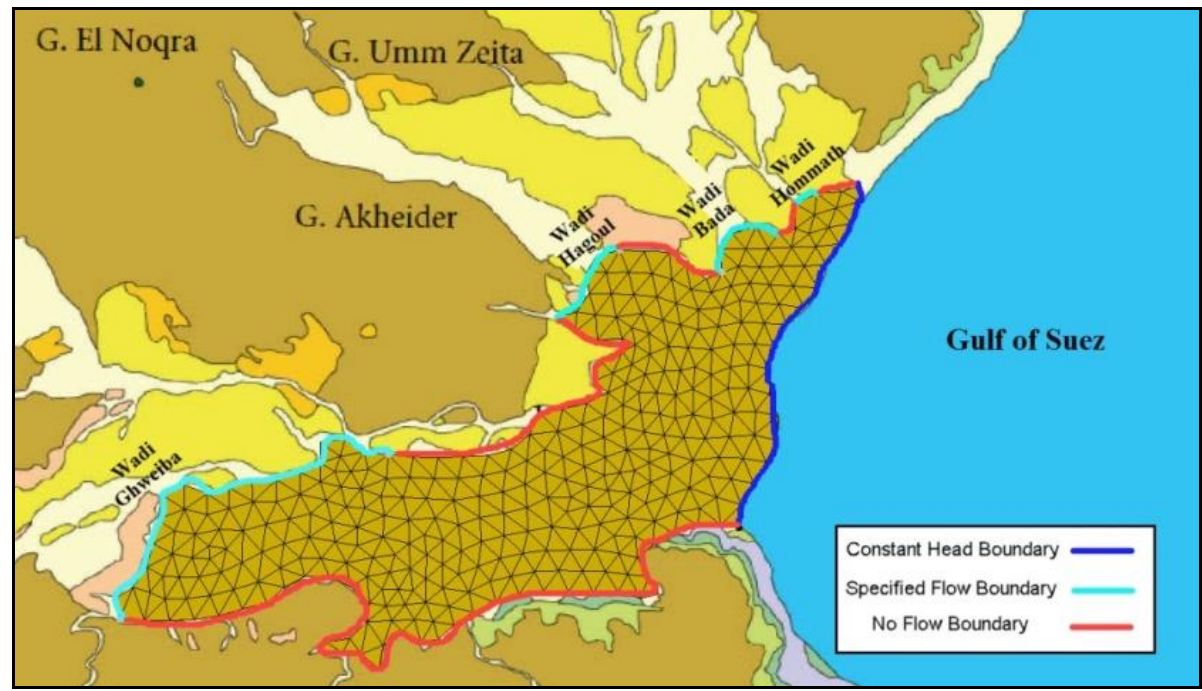

Figure (4): Hydraulic Boundaries of the Study Area

According to [24], the initial hydraulic conductivity values were $2.35,0.33$ and $1.68 \mathrm{~m} /$ day for the sand and gravel aquifer, limestone aquifer and sandstone aquifer, respectively.

Two main aquifer recharge resources in the study area were the rainfall and the floods in the wadis. The recharge from thesetwo sources was estimated by two methods.These methods were Soil Conservation Service curve number (SCS) method [25, 26] and Water Balance method [27].The initial recharge rate from rainfall was $1.10 \times 10^{-5} \mathrm{~m} /$ day and the flow rate values from the floods of wadis were $21.23,32.82,92.00$ and $416.55 \mathrm{~m}^{3} / \mathrm{day}$ for wadis Hommath, Hagoul, Bada and Ghweiba, respectively.

For calibration, the model is repeatedly run until the computed solution matches fieldobserved values within an acceptable level of accuracy [28].

For this study, a steady state calibration was carried out for the model. Transient calibration could not be done due to a lack of observation head data records throughout the study area and the transient calibration period. The steady state calibration was done by trial and error method. The forward model was run with the initial values of the hydraulic parameters, and a comparison between the results of the calculated and measured values of hydraulic head was carried out. This process was repeated until a satisfactory result was obtained.

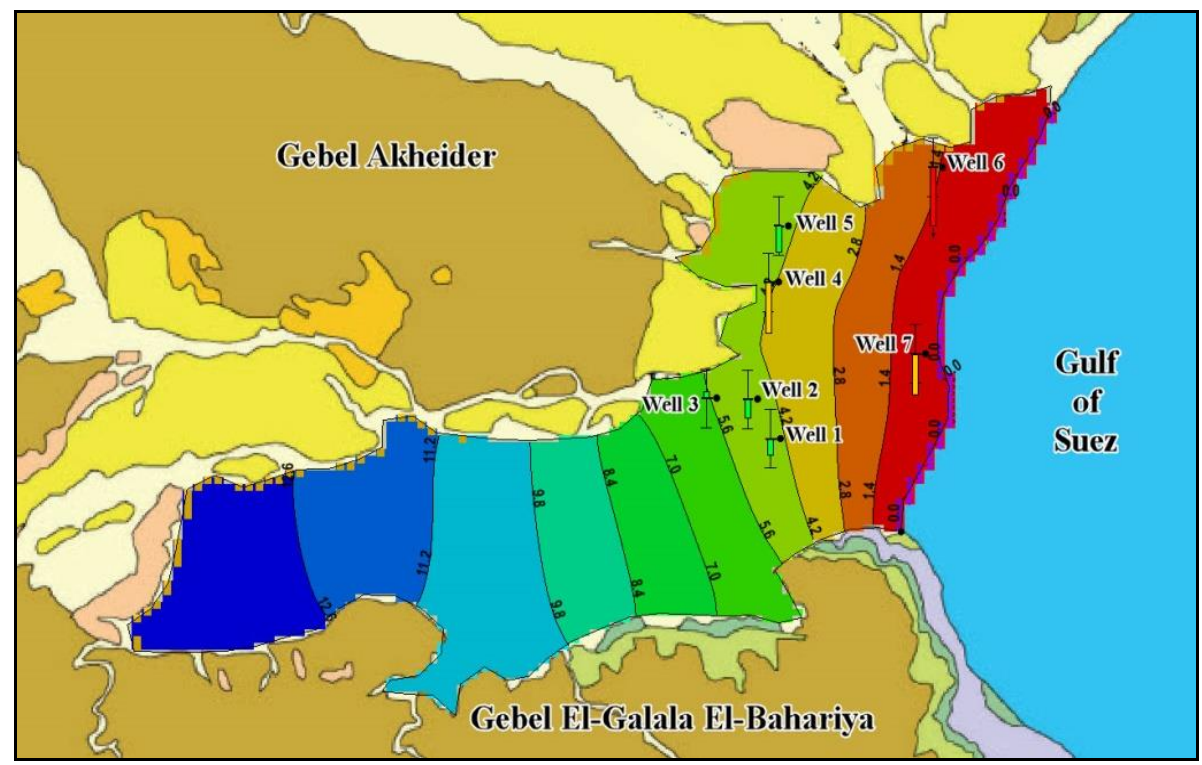

Figure (5): Head Contour Map with Calibration Targets

The calibration trials showed that the model was sensitive to some parameters (horizontal hydraulic conductivity and the rainfall recharge rate) more than the others. The hydraulic conductivity values at the northwestern part of the 
shallow, medium and deep aquifers were equal to $1.20,0.12$ and $1.50 \mathrm{~m} /$ day respectively while the rainfall recharge rate was $2.7 \times 10^{-5} \mathrm{~m} /$ day. Figure (5) shows the resulted head contour map of the steady state calibration phase of the model.

In order to obtain the best scenario for groundwater management, predictive simulations were performed under four different abstraction scenarios. These scenarios were the same abstraction, reduced abstraction by $25 \%$, increased abstraction by $25 \%$, and increased abstraction by $50 \%$. All the predictive simulations were performed from January 2020 to January 2120.

\section{DISCUSSION OF RESULTS}

\subsection{Groundwater Drawdown}

It was noticed that sand and gravel aquifer is the most influenced one since all wells were extracted from it. The maximum drawdown value of all scenarios was $26.81 \mathrm{~m}$ for this aquifer at the third scenario. For all scenarios, the maximum drawdown happened at the middle and northwestern parts of the study area where most of the wells were established. Then, the drawdown decreases gradually toward the east due to the inflow from the Gulf of Suez. The groundwater head distribution for the four abstraction scenarios are shown in Figures (6) through (9) for the sand and gravel aquifer.

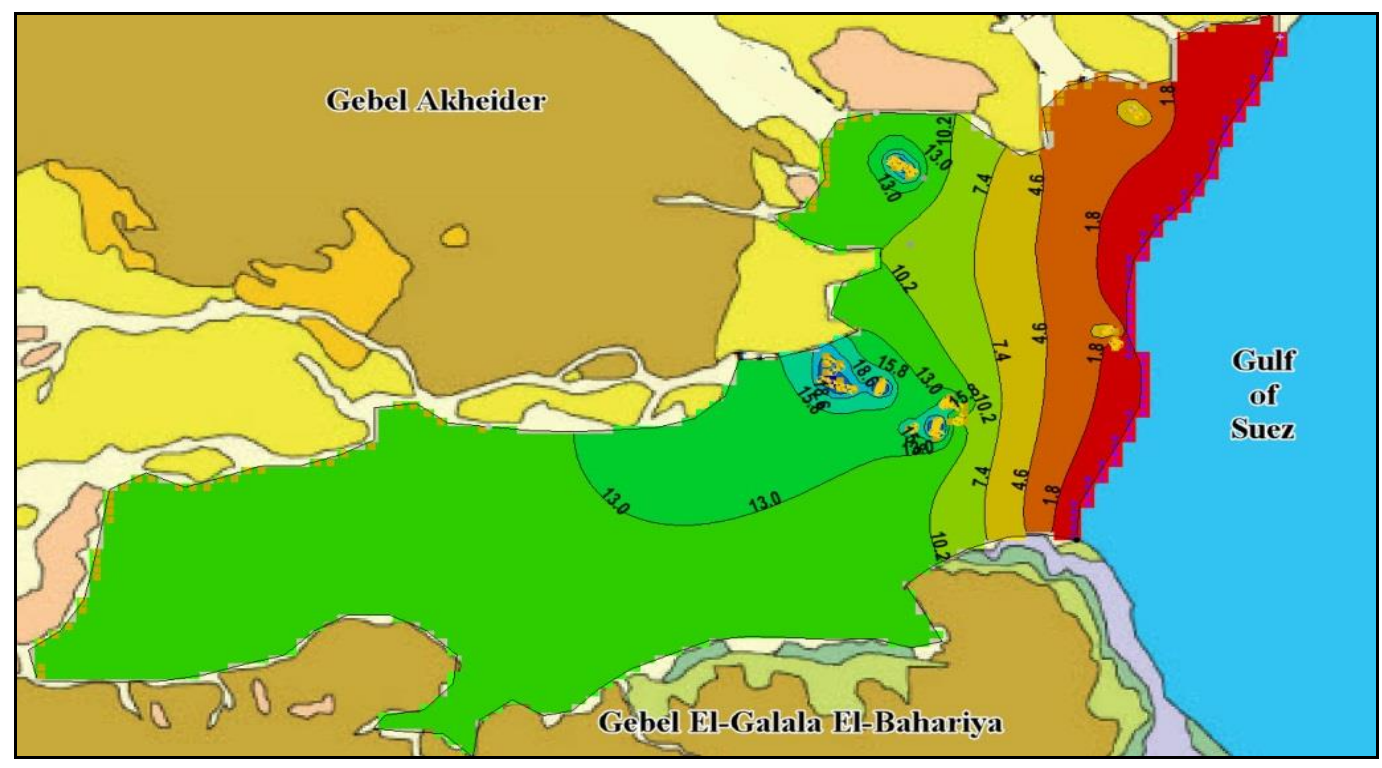

Figure (6): Drawdown Map for Sand and Gravel Aquifer for the First Scenario

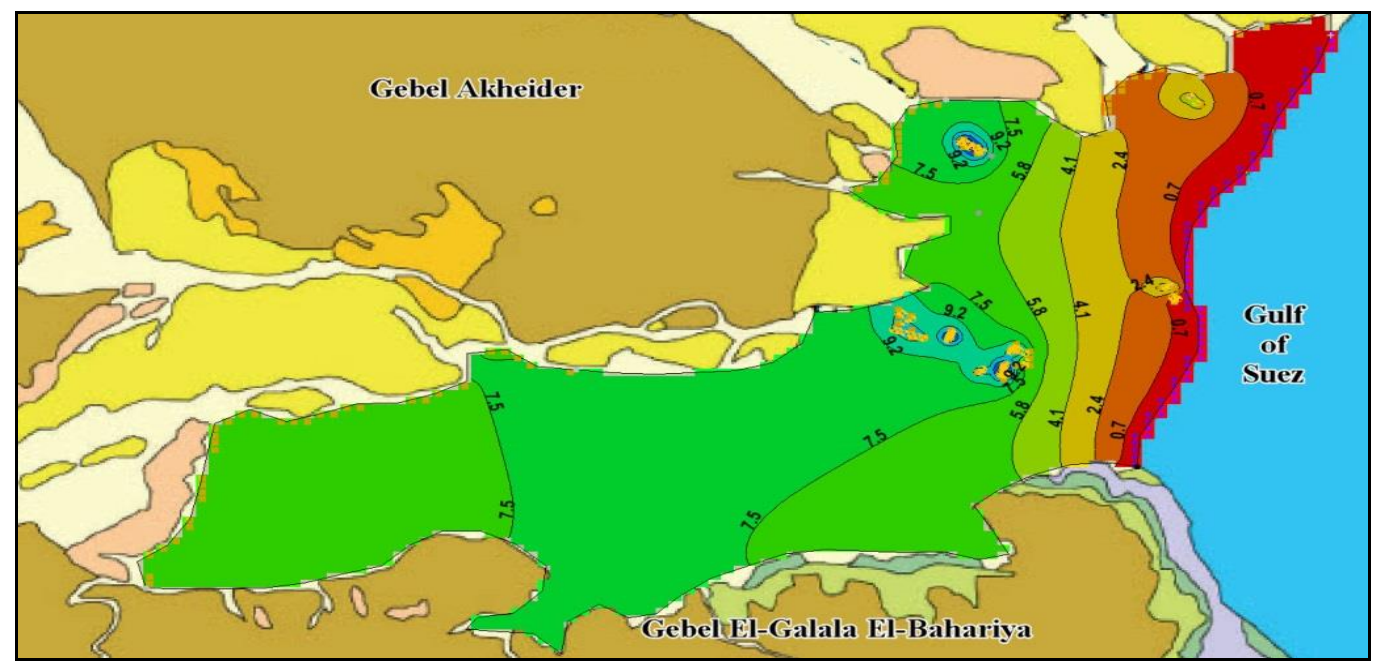

Figure (7): Drawdown Map for Sand and Gravel Aquifer for the Second Scenario 


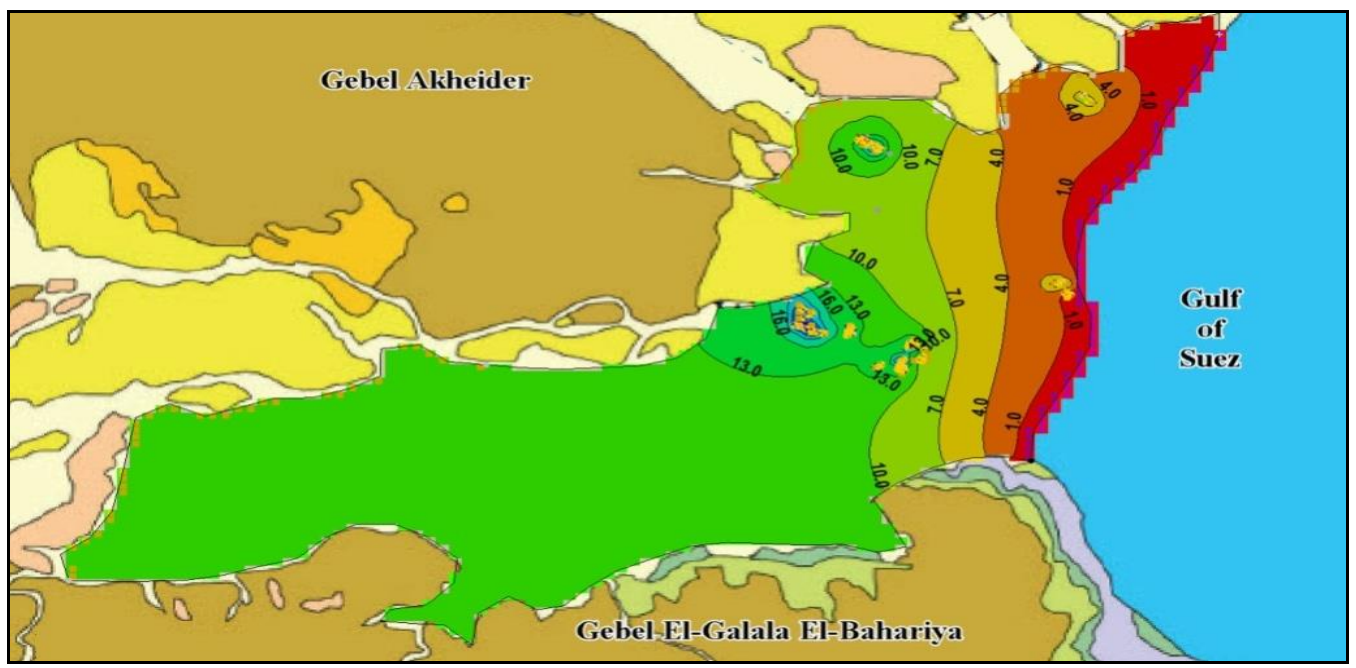

Figure (8): Drawdown Map for Sand and Gravel Aquifer for the Third Scenario

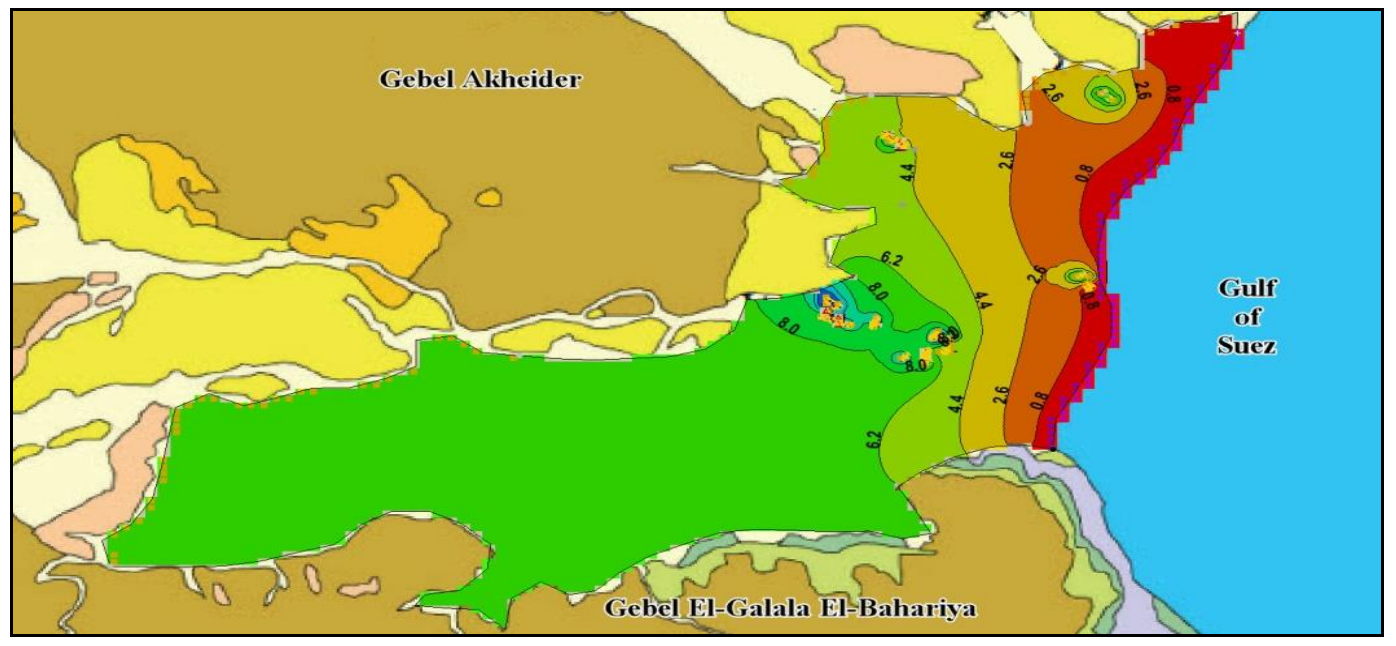

Figure (9): Drawdown Map for Sand and Gravel Aquifer for the Fourth Scenario

For all scenarios, it was remarkable that there were four zones of maximum drawdown for the sand and gravel aquifer due to the existence of most wells. So, some cells dried-up when increasing the abstraction rates in the third and fourth scenarios, which caused some existing pumping wells to stop. Figures (10) and (11) show close-up shots for the maximum drawdown zones and location of dried-up cells of the sand and gravel aquifer for the third and fourth scenarios. 


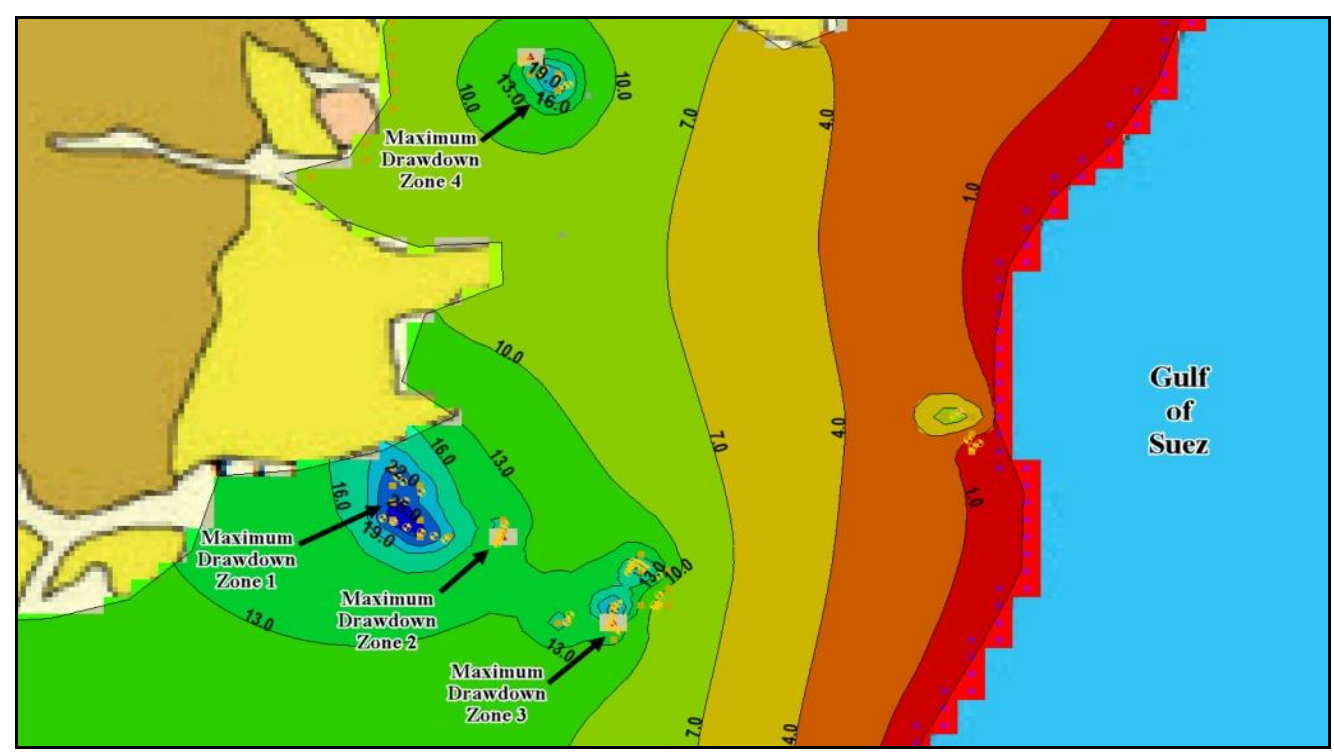

Figure (10): Maximum Drawdown Zonesand Dry-up Cellsfor Sand and Gravel Aquifer for the Third Scenario

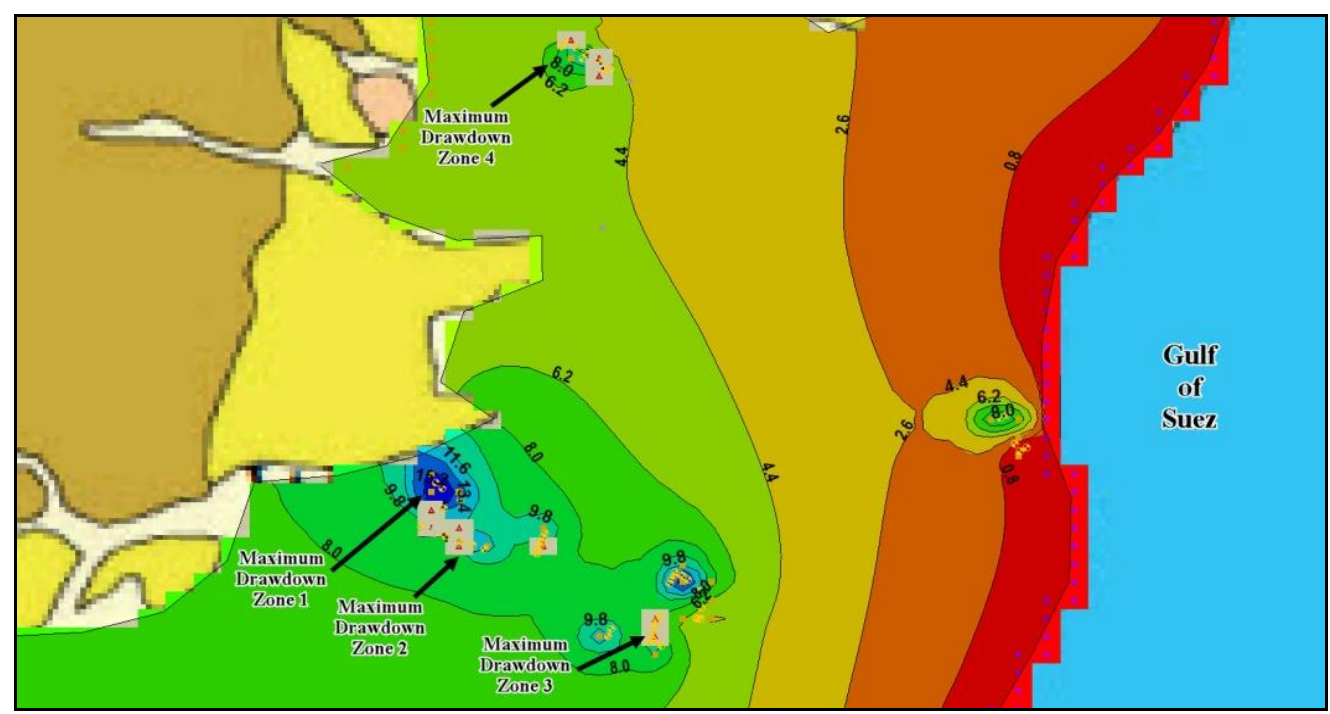

Figure (11): Maximum Drawdown Zonesand Dry-up Cellsfor Sand and Gravel Aquifer for the Fourth Scenario

The changes of drawdown with time through the prediction period were illustrated in Figures (12) through (15) for the sand and gravel aquifer for all scenarios. These charts clarified that the increase in drawdown of the sand and gravel aquifer would be slight for the next hundred years indicating a stable condition of the aquifer.

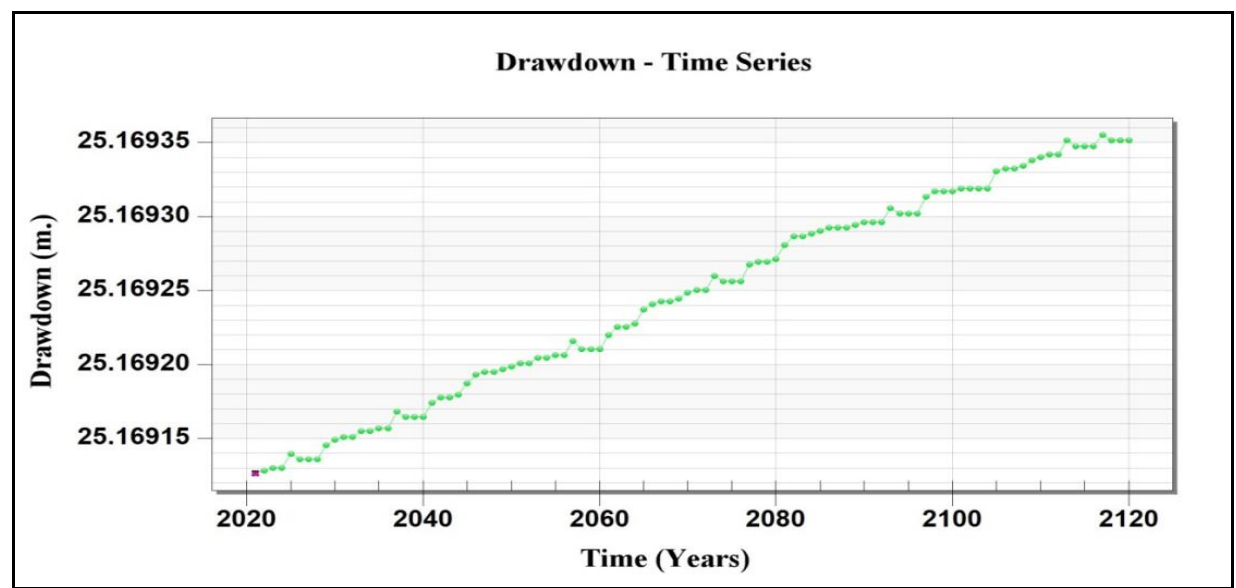

Figure (12): Drawdown - Time for Sand and Gravel Aquifer, First Scenario 


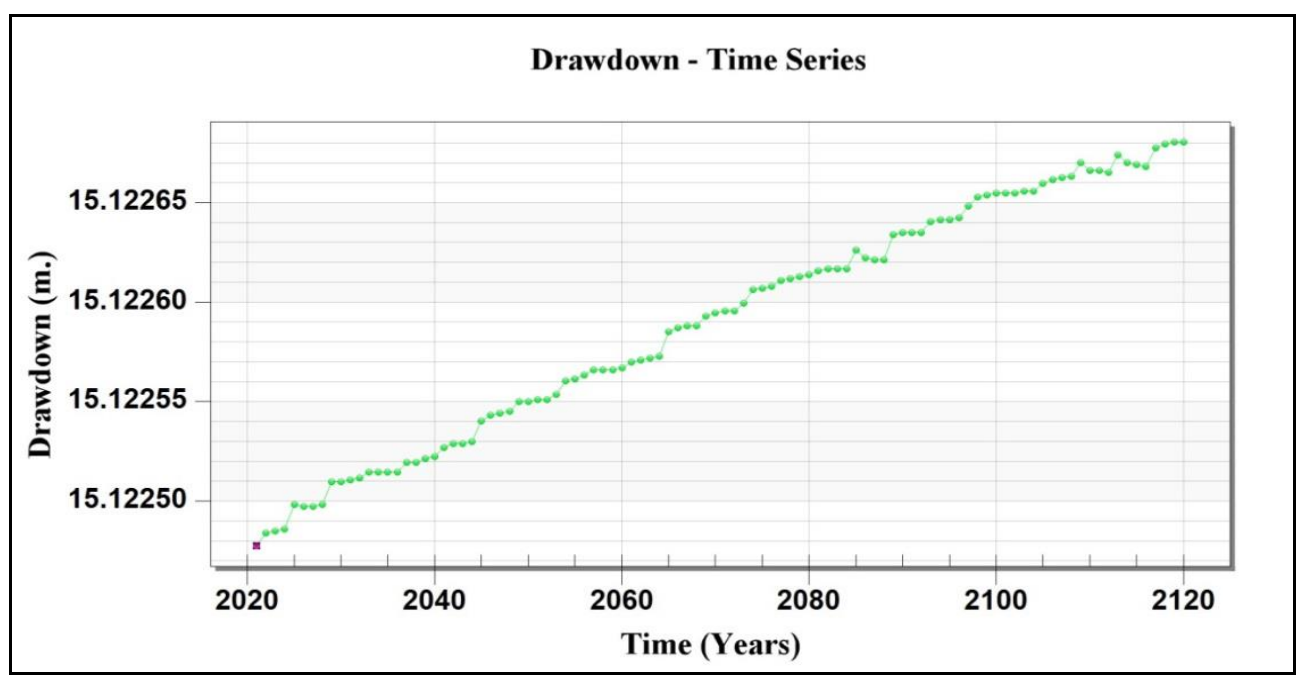

Figure (13): Drawdown - Time for Sand and Gravel Aquifer, Second Scenario

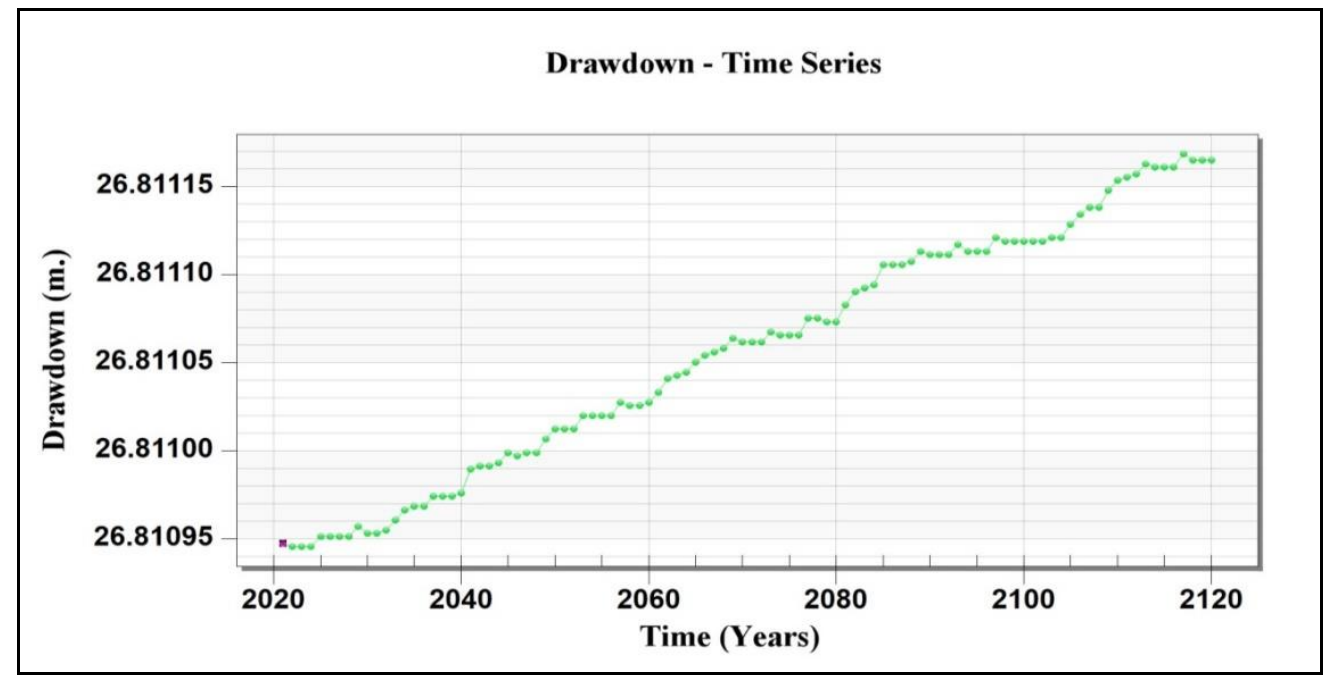

Figure (14): Drawdown - Time for Sand and Gravel Aquifer, Third Scenario

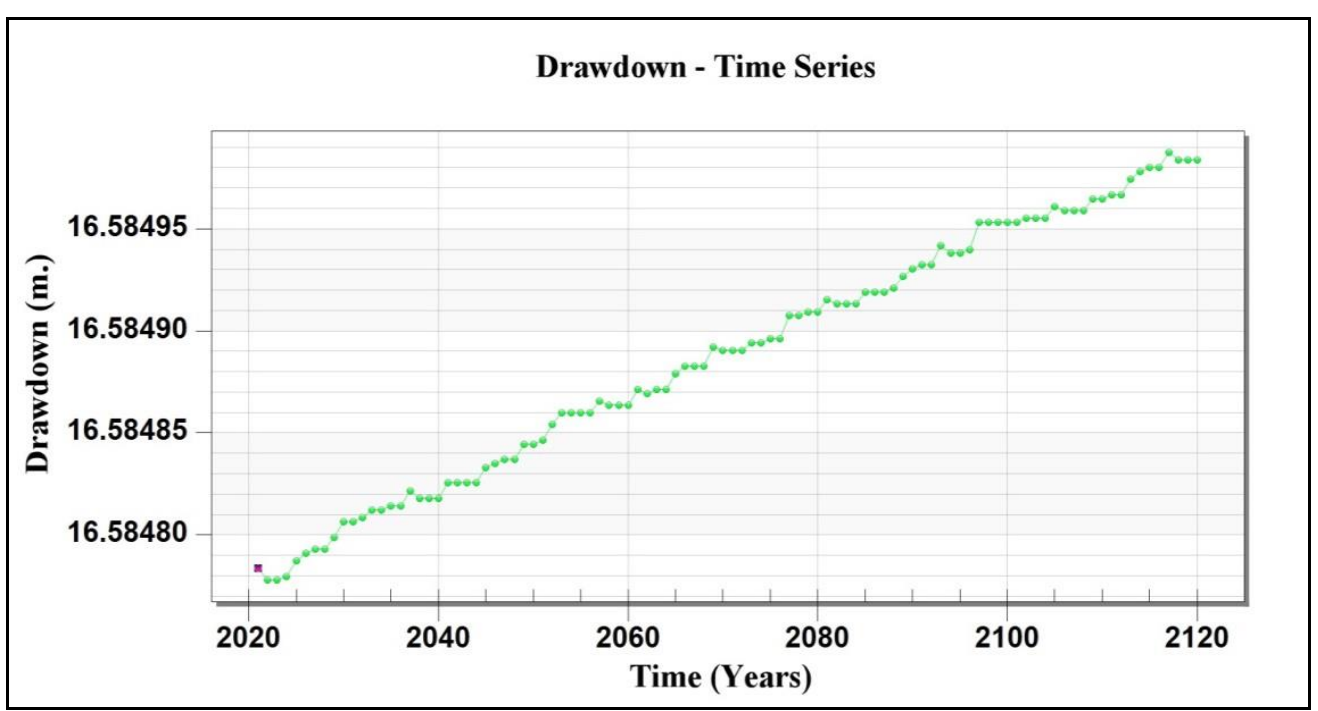

Figure (15): Drawdown - Time for Sand and Gravel Aquifer, Fourth Scenario 


\subsection{Flow Budget}

The flow budgets for the various scenarios are shown in Tables 1 to 4 .

Table (1): Flow budget of the model area for the first scenario

\begin{tabular}{|l|c|c|}
\hline Sources/Sinks & Inflow $\left(\mathbf{m}^{\mathbf{3}} / \mathbf{d}\right)$ & Outflow $\left(\mathbf{m}^{\mathbf{3}} / \mathbf{d}\right)$ \\
\hline Constant Head & 8635.422 & -96.113 \\
\hline Wells & 1588.543 & -15800.0 \\
\hline Recharge & 5672.543 & 0.0 \\
\hline Storage & 1.287 & -1.804 \\
\hline Total Source/Sink & 15897.795 & -15897.917 \\
\hline
\end{tabular}

Table (2): Flow budget of the model area for thesecond scenario

\begin{tabular}{|l|c|c|}
\hline Sources/Sinks & Inflow $\left(\mathbf{m}^{\mathbf{3}} / \mathbf{d}\right)$ & Outflow $\left(\mathbf{m}^{\mathbf{3}} / \mathbf{d}\right)$ \\
\hline Constant Head & 3618.008 & -158.707 \\
\hline Wells & 1268.543 & -10400.0 \\
\hline Recharge & 5672.543 & 0.0 \\
\hline Storage & 1.296 & -1.874 \\
\hline Total Source/Sink & 10560.390 & -10560.581 \\
\hline
\end{tabular}

Table (3): Flow budget of the model area for thethird scenario

\begin{tabular}{|l|c|c|}
\hline Sources/Sinks & Inflow $\left(\mathbf{m}^{\mathbf{3}} / \mathbf{d}\right)$ & Outflow $\left(\mathbf{m}^{\mathbf{3}} / \mathbf{d}\right)$ \\
\hline Constant Head & 7723.260 & -103.822 \\
\hline Wells & 1928.543 & -15220.0 \\
\hline Recharge & 5672.543 & 0.0 \\
\hline Storage & 1.225 & -1.875 \\
\hline Total Source/Sink & 15325.571 & -15325.697 \\
\hline
\end{tabular}

Table (4): Flow budget of the model area for thefourth scenario

\begin{tabular}{|l|c|c|}
\hline Sources/Sinks & Inflow $\left(\mathbf{m}^{\mathbf{3}} / \mathbf{d}\right)$ & Outflow $\left(\mathbf{m}^{\mathbf{3}} / \mathbf{d}\right)$ \\
\hline Constant Head & 3776.766 & -147.450 \\
\hline Wells & 2248.543 & -11550.0 \\
\hline Recharge & 5672.543 & 0.0 \\
\hline Storage & 1.256 & -1.837 \\
\hline Total Source/Sink & 11699.108 & -11699.287 \\
\hline
\end{tabular}

\section{CONCLUSIONS}

The main objective of this study was to evaluate and manage the groundwater for the aquifers in Ain Sukhna area. This was achieved with the aid of the Groundwater modeling system (GMS) version (10.3) software and other tools such as GIS and Google earth. The solid model was built with the help of the geological and hydrogeological data. Then, the conceptual model was built through defining boundaries, hydraulic properties of the aquifers and recharge values. The next step was to calibrate the model in steady state condition with the available data in order to prepare it for the prediction phase. Results from the calibration in steady state condition showed that the model calibration was successful according to the plot of computed versus observed heads.

A predictive simulation was conducted from January 2020 to January 2120 where the model was examined for the influence of different abstraction scenarios on the three aquifersof the study area. The results of these scenarios showed 
that the maximum drawdown occurred at the sand and gravel aquifer was more than those occurred at both the limestone and sandstone aquifers, especially at the middle and northwestern parts of the study area where most of the wells were established.

The results showed also that a $25 \%$ increase in the current abstractionrates could lead to a sharp decrease in the levels of groundwater, especially at the sand and gravel aquifer that may cause the depletion of this aquifer at some zones of the study area. For this reason, it is preferable to maintain current abstraction rates, or even better to reduce them, in order to maintain the groundwater.

Also, in the future, horizontal expansionswill be desirablefor digging and establishing new proposed wells in order to take advantage of the groundwater optimally that does not affect its sustainability and non-deterioration in quantity and quality.

\section{ACKNOWLEDGMENTS}

All thanks and appreciation to the staff of Shoubra Faculty of Engineering and Water Resources Research Institute who contributed to the completion of this work.

\section{REFERENCES}

[1] Abdallah A. (2007)."Monitoring Environmental Changes in El-Ain El-Sokhna Area, Gulf of Suez, Egypt". Nine conference for geographical and GIS Department, Faculty of Arts, Alexandria University.

[2] Shata A. (1955). "Some remarks on the distribution of the Carboniferous Formations in Egypt", Bulletin de l'Institut du D'esertd'Egypte, Vol. 5, no. 1, pp. 241-247.

[3] Kostandy A. B. (1959). "Facies maps for the study of the Paleozoic and Mesozoic sedimentary basins of the Egyptian region". Proceedings of the $1^{\text {st }}$ Arab Petroleum Congress, pp. 54-62, Cairo, Egypt.

[4] Said R. (1962). "The Geology of Egypt", A. A. Balkema, Rotterdam, The Netherlands.

[5] Said R. (1990). "The Geology of Egypt", A. A. Balkema, Rotterdam, The Netherlands.

[6] United Nation (UN) (1979). "Structure plan for Suez Governorate", Draft final report, V.II, groundwater resources investigations, Nor-consult A. S. and MECO.

[7] Cement Suez Company (1981). "Groundwater hydrology of wadi Badaa quantitative analysis, development and plan of operation for the supply of water requirements to the Suez Cement Company", Internal Report.

[8] Arabian Geophysics (1987). "Drilling and well logging for the productive wells to for the Suez Cement Company", Internal Report.

[9] Mostafa A. S. (1993). "Geophysical studies on the area of northwest of Suez", M. Sc. Thesis, Faculty of Science, Ain Shams University, Cairo, Egypt.

[10] Helal A. M. A., El Sayed A. A., Mousa S. A. and El-Meliegy H. (1995). "Seismic facies analysis of Mesozoic rocks of the Cairo-Suez District". Proceedings of the $13^{\text {th }}$ Annual Meeting of the Egyptian Geophysical Society, pp. 59-80, Cairo, Egypt.

[11] AbdAllatief A. T., Galal G. H. and Youssef A. M. A. (1997). "Structural and lithological impacts on the groundwater occurrences along wadi El Naqra-wadi Badaa area, (a case study)". Proceedings of the $15^{\text {th }}$ Annual Meeting of the Egyptian Geophysical Society, pp. 107-124, Egyptian Geophysical Society.

[12] AboulEla A. M. (2001). "Seismic response analysis of the foundation rocks of El-Ain Ei-Sukhana area Gulf of Suez Egypt as determined from seismic refraction technique”. Geological Survey of Egypt, Vol. 24, pp. 555565.

[13] El Houseiny M. (2002). "Geophysical studies on the water bearing formations in Ain El-Sukhana area", M.Sc. Thesis, Faculty of Science, Cairo University, Cairo, Egypt.

[14] Nasr I. M. (2004). "Geophysical exploration for groundwater aquifers in Wadi Ghawaiba area, West Gulf of Suez", Journal of Faculty of Educational, no. 29, pp. 131-145.

[15] El Osta M. M., El Sheikh A. El. and Barseem M. S. (2010). "Comparative Hydrological and Geoelectrical Study on the Quaternary Aquifer in the Deltas of Wadi Badaa and Ghweiba, El Ain El Sukhna Area, Northwest Suez Gulf, Egypt". International Journal of Geophysics, Volume 2010, Article ID 585243, 15 pages.

[16] Othman A. A., Abd El-Hafez Th. H., Youssef M. A. and Sabra M. E. (2013). "Shallow Geophysical Techniques for Groundwater Aquifer Exploration, Ain Alsokhona Area, West Gulf of Suez, Egypt", Researcher Science Journal 2013; 5(6): 30-41 (ISSN: 1553-9865).

[17] Sultan S. A., Mohamed A. M. and Santos F. M. (2016). "Geophysical Investigation in the Northwestern Part of the Gulf of Suez, Egypt", Egyptian Journal of Petroleum (2017) 26, 457-475.

[18] Khalaf S. and Abdalla M. G. (2014). "Groundwater Modeling of Multi-Aquifer Systems Using GMS", Hydrology Current Research, Volume 6, Issue 1, 1000184.

[19] Eltarabily M. G., Negm A. M., Yoshimura C. and Takemura J. (2017). "Groundwater Modeling in Agricultural Watershed under Different Recharge and Discharge Scenarios for Quaternary Aquifer Eastern Nile Delta, Egypt", Environmental Modeling \& Assessment. doi:10.1007/s10666-017-9577-z. 
[20] Bear J. (1979). "Hydraulics of Groundwater". McGraw-Hill, New York.

[21] Rausch R. (2010). "Groundwater Modelling: An introduction to groundwater flow and solute transport modelling with applications", Technische Universitat Darmstadt.

[22] Anderson M. and Woessner W. (1992)."Applied groundwater modeling. Simulation of Flow and Advective Transport". San Diego, California: Academic Press Inc.

[23] Reilly T. (2001). "System and Boundary conceptualization in ground-water flow simulation. Techniques of water resources investigations of the U.S. Geological Survey". Book 3, Applications of Hydraulics. Chapter B8. Department of Interior. U.S. Geological Survey.

[24] Water Resources Research Institute (WRRI) (2013). "Technical Reports of Upper, Middle and Lower Wells in Wadi Bada - Ain Sukhna - Egypt", Internal Report.

[25] NRCS (2009)b. Part 630, Hydrology National Engineering Handbook, Chapter 7: Hydrologic Soil Groups.

[26] Cronshey R. (1986). "Urban Hydrology for Small Watersheds". US Department of Agriculture, Soil Conservation Service, Engineering Division.

[27] Gomaa M. A., Mohallel S. A. and Elsheikh A. E. (2016). "Estimation of Recharge Quantity of the Fractured Basement Aquifer in the Southern Portion of Eastern Desert, Egypt; Critical Importance of the Hydrological and Chemical Criteria." Middle East Journal of Applied Sciences, 6, 759-773.

[28] Aquaveo (2018). MODFLOW - Automated Parameter Estimation. GMS 10.4 Tutorial. 